\title{
Performance and Techno-Economic Analysis of Scaling-up A Single-Chamber Yeast Microbial Fuel Cell as Dissolved Oxygen Biosensor
}

\author{
Marcelinus Christwardana*, Linda Aliffia Yoshi
}

Department of Chemical Engineering, Institut Teknologi Indonesia, Jl. Raya Puspitek Serpong, South Tangerang, 15320 Indonesia

\begin{abstract}
The Microbial fuel cells (MFCs) are electrochemical devices that can be utilized as biosensors, specifically Dissolved Oxygen (DO) biosensors. In this research, performance and techno-economic of MFC-based DO biosensors with two sizes, small and large, were evaluated and analysed to determine whether it is more economical to use a small or large reactor. MFC-based DO biosensors were also applied to an irrigation canal. When MFC immersed into distilled water with several variations of DO, the correlation between DO and current density produced equation with $\mathrm{R}^{2}$ values around 0.9989 and 0.9979 for SYMFC and LYMFC, respectively. The power density for SYMFC and LYMFC was 3.48 and $10.89 \mathrm{~mW} / \mathrm{m}^{2}$, respectively, in DO 6. Higher power densities are correlated with the electrode surface area, especially the larger cathodic surface area. When applied to the irrigation canal, DO values measured using SYMFC and LYMFC have errors of around 3.39 and $4.42 \%$, respectively, when compared to DO values measured using DO meters. LYMFC requires a capital cost of around $\$ 234.22$ or 2.57 times higher than SYMFC, although it generates almost similar cost per $\mathrm{mW} / \mathrm{m}^{2}, \$ 21.51$ and $\$ 26.23$ for LYMFC and SYMFC, respectively. The results concluded that yeast MFC -based DO biosensors with smaller sizes can achieve more economical compared to larger sizes.
\end{abstract}

Keywords: Environmental Biosensor, Single-chamber MFC, Economic Analysis, Energy-to-cost Ratio, Saccharomyces cerevisiae

Article History: Received: 07th May 2020; Revised: $5^{\text {th }}$ July 2020; Accepted: $1^{\text {st }}$ August 2020; Available online: $16^{\text {th }}$ August 2020

How to Cite This Article: Christwardana, M. and Yoshi, L. (2020) Performance and Techno-Economic Analysis of Scaling-up A Single-Chamber Yeast Microbial Fuel Cell as Dissolved Oxygen Biosensor. International Journal of Renewable Energy Development, 9(3), 449-454 https://doi.org/10.14710/ijred.2020.29980

\section{Introduction}

Microbial fuel cells (MFCs) are devices for oxidizing organic and inorganic materials and producing electricity by using microorganisms as biocatalysts (Logan and Regan, 2006; Rabaey et al 2006). Electrical energy can be generated by placing anode in anode chamber and feed them with anolyte which consisting substrates and biocatalysts, and then connecting them via electronic circuits to cathode electrodes containing catholyte in the form of oxygenated water (Bond et al 2002; Lowy et al 2006). The electrons produced by oxidation from organic matter in the substrate by microorganisms and travel through an external circuit to the cathode electrode. Meanwhile, protons diffuse into the cathode space via proton exchange membrane (PEM), where protons will react with electrons and oxygen molecules to form water (Rezaei et al 2007; Tender et al 2002).

MFC has a variety of functions and is very broadly applied to various aspects, for example, waste treatment, electricity production, as well as being used as an environmental biosensor (Zhang and Angelidaki, 2011; Schneider et al 2016; Yang et al 2015). The environmental biosensor is one crucial aspect because it is one of the devices that can help indicate environmental sustainability. MFC-based environmental biosensors are usually used as indicators of COD, BOD, DO, microorganism activity, or toxic substances (Vishwanathan et al 2013; Zhang et al 2011; Oh et al 2009; Shen et al 2013; Tront et al 2008). Usually, samples from environmental waters containing organics or inorganics matter flowed into the anode chamber where a consortium of microorganisms placed, make the voltage differences occur, and passed on as a signal. Environmental water samples can also flow into the catholyte chamber when the characterization of the sample is related to oxygen activity.

Dissolved oxygen (DO) is one of the most critical and often used parameters related to water quality, which is an essential indicator of microbial metabolic activity in aquatic samples (Wetzel, 2001; Ansa-Asare et al 2000). DO concentrations in waters provide important information regarding biological activities that involve biochemical reactions in the aquatic environment. Therefore, DO can be used to measure the activities of biological processes that occur in environmental waters (Markfort and Hondzo, 2009).

\footnotetext{
* Corresponding author: marcelinus@iti.ac.id
} 
Yeast MFC is considered an alternative renewable resource that can be utilized as a biosensor. Some of the advantages of yeast as a biocatalyst in MFC include yeast has facilitated extracellular electron transfer, robust, fastgrowing, facultative anaerobe, non-pathogen, and temperature tolerant biocatalyst (Hubenova and Mitov, 2015; Rossi et al 2015; Rossi et al 2016). However, its low output power and voltage are the main limitations of the MFC yeast, which will affect the performance of the biosensor. Yeast MFCs reportedly provide power densities that vary between $0.95-2771.25 \mathrm{~mW} / \mathrm{m}^{2}$ (Duarte et al 2019, Powell et al 2011), depending on the substrate, electrodes, and polarization data collection methods. Several studies have been carried out by several researchers whose base aims to improve the performance of yeast MFC. Modification of anode material, the effect of adding several types of mediators and their reaction studies, as well as optimization of the substrate on the anode side have been carried out (Christwardana et al 2018a; Christwardana et al 2018b; Christwardana et al 2018c; Christwardana et al 2019). Considering these matters, it is possible that the MFC yeast can be used as a promising DO biosensor for environmental waters.

Air and water-compatible, good sensitivity and selectivity, scalable, cheap, unique, and environmentally friendly are the preferred biosensor characteristic (Rawson et al 1989; Karube et al 1995; Dennison and Turner, 1995; Badihi-Mossberg et al 2015). Regarding scalability, reactor size is an important issue for the application of MFCs as biosensors, especially DO biosensors. However, there is little information available about the effects of biosensor scaling on its power output. Therefore, an assessment of the effect of biosensor measures on performance must be carried out intensively. The scale correlation of the performance of MFC-based biosensors can be used as a reference for researchers to develop later biosensors that are more compact, accurate, economical, and have good performance.

In this study, we operate an MFC-based DO biosensor, which had small in size, and then compares it with a larger size. With relatively larger the anode surface area and anolyte volume, and without reducing the electrode spacing, the performance between the small and large size
DO biosensors would be compared, and then the economic analysis would be assessed. We hope this study can be used as a reference for determining dimensions and designing MFC reactors as environmental biosensors.

\section{Materials and Methods}

\subsection{MFC-based DO Biosensor Construction}

Single chamber acrylic MFC reactor (Phychemi, Hongkong) used as environmental DO biosensors with a liquid volume of $28 \mathrm{~mL}$ and a $4 \mathrm{~cm}$ electrode space from both electrodes, then called Small Yeast Microbial Fuel Cell (SYMFC). The anode and cathode were made of carbon felt with an active area of $7 \mathrm{~cm}^{2}$ and treated Nafion 117 (treated with $3 \%$ w/w $\mathrm{H}_{2} \mathrm{O}_{2}, 0.5 \mathrm{M} \mathrm{H} \mathrm{H}_{2} \mathrm{SO}_{4}$, and DI water) acted as a membrane separator between the anode and the cathode (Christwardana et al 2018a; Christwardana et al 2018b). Meanwhile, a single chamber acrylic MFC reactor with a larger size (home-made) had a higher volume of liquid, which was $154 \mathrm{~mL}$ was used as a comparison, with the space of the two electrodes was $4 \mathrm{~cm}$, then called Large Yeast Microbial Fuel Cell (LYMFC). The active surface area of anode, cathode, and membrane separator increased to $38.48 \mathrm{~cm}^{2}$ or 5.5 times higher. The photograph of the small and large MFC reactor can be shown in Figure 1a-c.

\subsection{MFC-based DO Biosensor Operation}

MFC was inoculated using $14 \mathrm{mg} / \mathrm{mL}$ yeast Saccharomyces cerevisiae (Lessafre, Marcq-en-Baroeul, France) and fresh nutritional media consisting of 14 $\mathrm{mg} / \mathrm{mL}$ glucose (Merck, Darmstadt, Germany), $5 \mathrm{mg} / \mathrm{mL}$ yeast extract (Merck, Darmstadt, Germany), and 2.5 $\mathrm{mg} / \mathrm{mL}$ peptone (Himedia, Mumbai, India) (Christwardana et al 2018c; Christwardana et al 2019) was fed into anode chamber every three days for two weeks, to grow biofilm on the anode surface. The system was considered to be operating in a stable condition when the voltage can be reproduced after refilling the reactor with the fresh medium during the incubation.

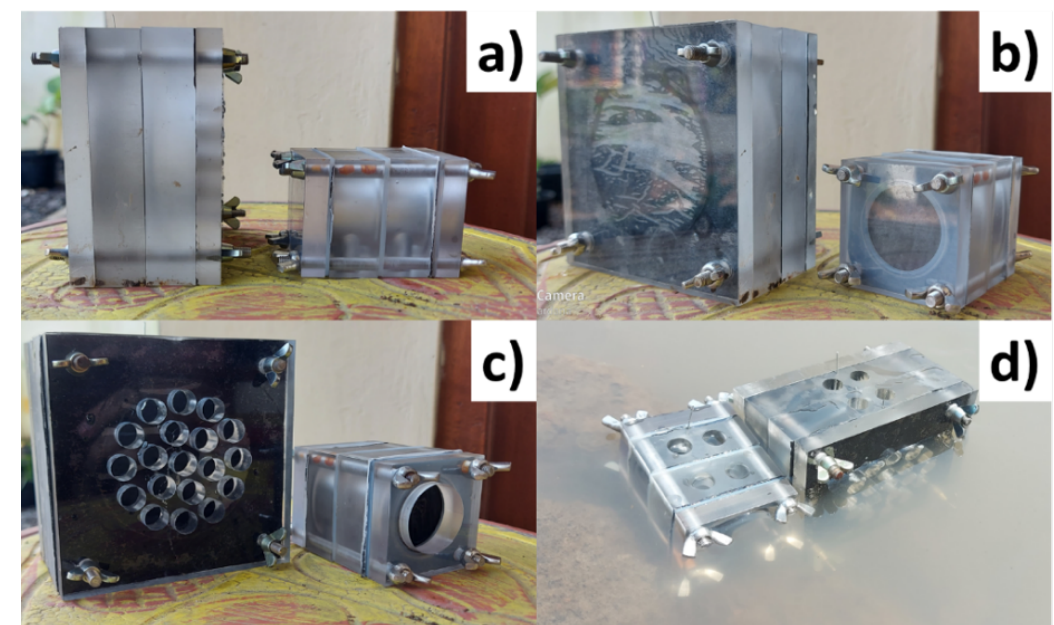

Fig. 1 a) Lateral, b) front, and c) back views of assembled small and large MFC reactor. While d) is their application in the irrigation canal 
Once stable, the MFC yeast system is then put into a container containing distilled water (DW) and operated with different DO volumes. Aeration system was used to increase DO concentrations, while $\mathrm{N}_{2}$ gas was used to reduce DO concentrations. The anode and cathode are connected to an external circuit with a $1000 \Omega$ external resistance. The voltage was taken for 30 minutes by recording every 5 minutes and converted to current density. As a calibration, DO concentration was measured using a commercial DO meter Lutron WA-2015 (Taipei, Taiwan). The equation obtained from the DO vs. current density curve. The equation was used to predict DO concentration using MFC when applied to environmental waters samples.

MFC was applied to an irrigation canal in Salatiga (Central Java, Indonesia) as in Figure 1d, the voltage was measured using a multimeter UNI-T UT61E (Dongguan, China), and DO was measured using a DO meter, for 30 minutes. The current density value, which was the conversion of the voltage, was then entered into the equation obtained previously to obtain the $\mathrm{DO}$ value. Then the DO value of the MFC was compared to the $\mathrm{DO}$ value of the DO meter.

Finally, a polarization curve was obtained by measuring a stable voltage for 15 minutes, which results in various external resistance values from $5 \mathrm{M} \Omega$ to $100 \Omega$.

\subsection{Techno-economic Analysis of MFC-based DO Biosensor}

The techno-economics of MFC-based DO biosensors were analysed based on the cost of power obtained, both MFC in small and large sizes. The price of each component of MFC is added up (cost per cell), then divided by the power density obtained $\left(\mathrm{mW} / \mathrm{m}^{2}\right)$. A small cost of power is desirable while still considering its capital cost.

\section{Results and Discussion}

\subsection{Correlation Between DO and Current Density}

Both SYMFC and LYMFC were tested in DW with varying DO concentrations and an external resistance of $1000 \Omega$, as illustrated in Figure 2a. The resulting current density increased gradually as the DO concentration raised. Contrary, the current density decreased when the DO level reduced with the addition of $\mathrm{N}_{2}$ gas. The increase of DO levels made the cathodic potential value shifted in a more positive direction. Assuming the anodic potential has a fixed value, the cell potential or the difference between the cathode potential and the anode will be even more enormous in value. Large potential cell values affect the current density generation. The current density values at the initial DW were 10.1 and $16.7 \mathrm{~mA} / \mathrm{m}^{2}$ for SYMFC and LYMFC, respectively, at DO concentrations of $6 \mathrm{ppm}$. This value gradually raised when DO was increased to around $8 \mathrm{ppm}$ and produced a current density of around 19.4 and $39.1 \mathrm{~mA} / \mathrm{m}^{2}$ for SYMFC and LYMFC, respectively. Surprisingly, the current density value decreased to 1.2 and $2.0 \mathrm{~mA} / \mathrm{m}^{2}$ for SYMFC and LYMFC, respectively, when $\mathrm{N}_{2}$ gas was injected into $\mathrm{DW}$ to make anaerobic conditions. The reducing DO level makes the cathode potential shifted more negatively, so that the potential difference between the anode and cathode (cell potential) becomes small, as well as its current density value.
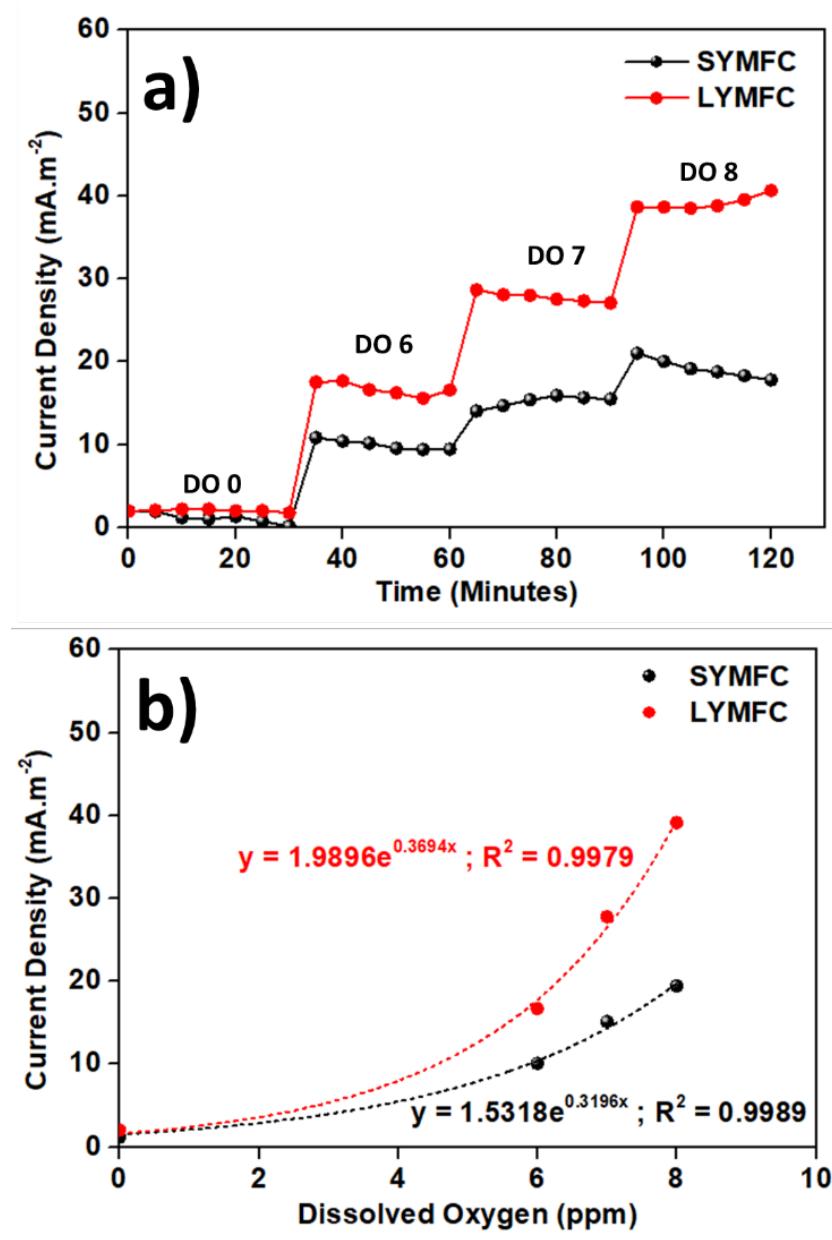

Fig. 2 a) Current density of Yeast MFC based biosensor in various DO concentration and b) correlation between DO level vs. current density

Figure $2 \mathrm{~b}$ shows the correlation between DO concentration and current density in SYMFC and LYMFC. Several things can be studied. First, the correlation between DO levels and current density did not indicate a linear increase, but rather an exponential. The values of $\mathrm{R}^{2}$ were 0.9989 and 0.9979 for the exponential equation in SYMFC and LYMFC, respectively. This is because the low DO concentration limited the cathode ORR activity in MFCs (Rismani-Yazdi et al. 2008; Rago et al.,2017). While higher DO, concentration can significantly increase current density production due to increased Oxygen Reduction Reaction (ORR) activity. Second, the current density produced in LYMFC was higher than SYMFC, which affected by two things, namely the surface area of the separator membrane and the cathode. The higher the surface area, the more protons diffused from the anode to the cathode. This is consistent with experiments carried out by Oh and Logan (2006) and Hadiyanto et al (2019), which stated that the area of the membrane affects the produced current density. The area of the cathode also affects the generation of current density. The ORR will occur more when the surface area of the cathode gets bigger. The ORR rate influences the rate of proton transfer from the anode to the cathode, where the rate of proton diffusion is proportional to ORR activity. 


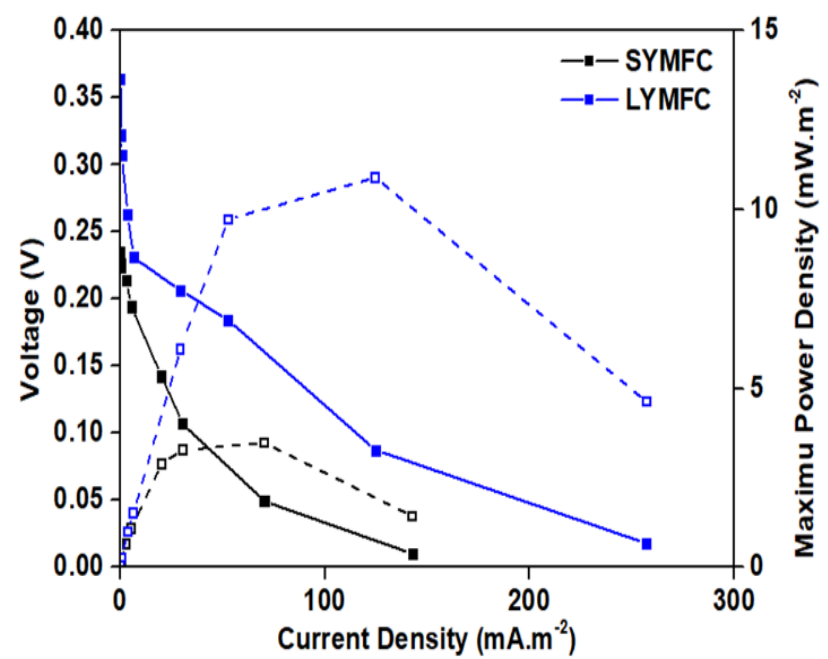

Fig. 3 Maximum Power Density of Yeast MFC as a DO biosensor. For the test, distilled water with average DO concentration was 6 used as the sample

\subsection{Maximum Power Density of Yeast MFC}

The performance of SYMFC and LYMFC as DO biosensors was investigated by measuring and making the polarization curve in DW without the influence of external oxygen. Figure 3 shows the MPD from SYMFC, where the result was $3.48 \mathrm{~mW} / \mathrm{m}^{2}$, while the MPD on LYMFC has a value of $10.89 \mathrm{~mW} / \mathrm{m}^{2}$ or higher 3.13 times higher. These results prove the truth that the energy produced by MFCs is influenced by several factors, including the surface area of the separator membrane and the surface area of the cathode. Current density is directly proportional to power density, $\mathrm{P}=\mathrm{Vx} \mathrm{I}$, so the increase in current density affects the increase in the value of power density.

\subsection{Application of Yeast MFC as DO Biosensor}

SYMFC and LYMFC as DO biosensors were applied to the irrigation canal, which has a flow rate of $0.125 \mathrm{~m} / \mathrm{s}$. The placement position of SYMFC and LYMFC in the river flow can be seen in Figure 4. The value of the current density of SYMFC and LYMFC was measured using multimeter, as well as the DO value of the river flow measured using DO meter for 30 minutes, as seen in Figure $5 \mathrm{a}-\mathrm{b}$. The average current density value in SYMFC was $14.45 \pm 0.55 \mathrm{~mA} / \mathrm{m}^{2}$, while in LYMFC was $21.91 \pm 1.55$ $\mathrm{mA} / \mathrm{m}^{2}$. The average $\mathrm{DO}$ value at that time was $6.79 \pm 0.09$ $\mathrm{ppm}$. The current density value obtained is then entered in the equation obtained on the DO vs. current density curve in Figure 2b. From these equations, the DO values obtained were 7.02 and 6.49 for SYMFC and LYMFC, respectively. DO values obtained in SYMFC had a percent error of $3.39 \%$, smaller than LYMFC, which had a \% error of $4.42 \%$. From this, we know that in addition to power density, the \% error in DO measurements is influenced by the architecture and size of the MFC. This is consistent with references stating that the size and architecture of MFCs affect the surface area of electrodes and membranes, and also the volume of electrolytes present in the anode and/or cathode chamber (Lanas et al 2014; Fan et al 2012; Cheng and Logan, 2011).
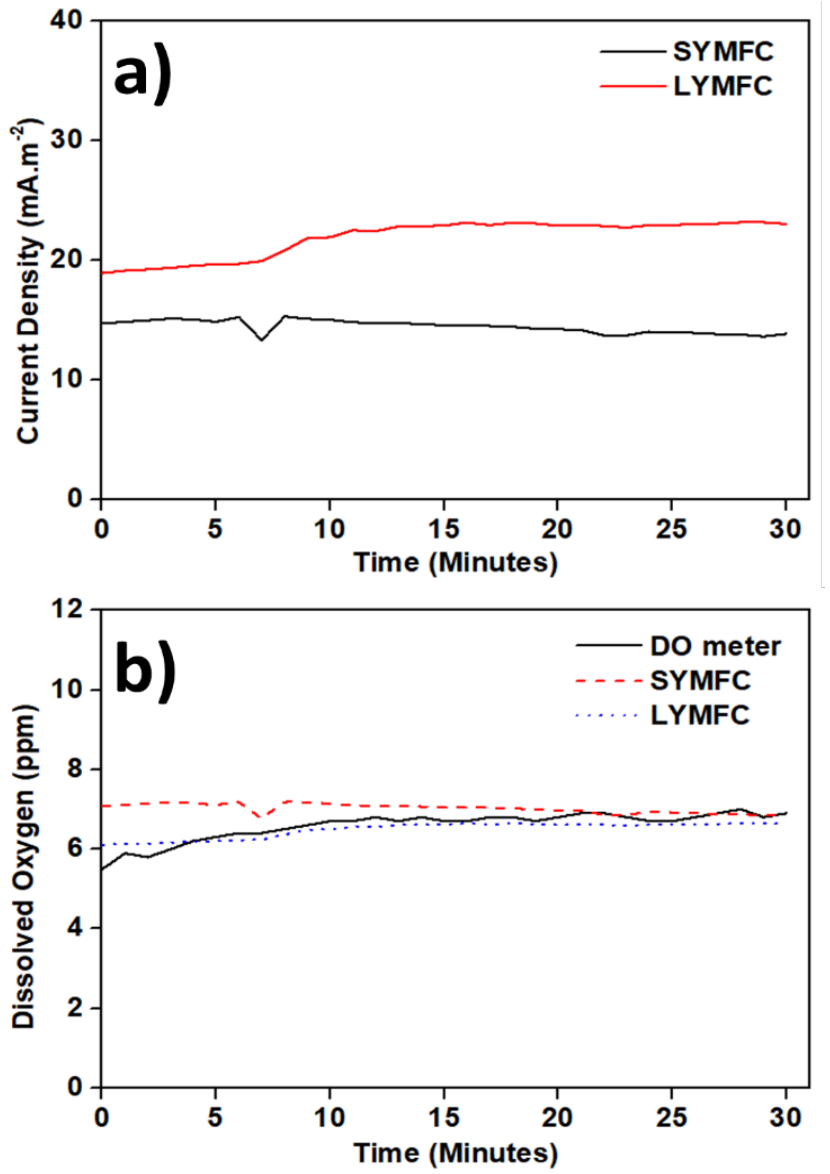

Fig. 4 a) Current density of SYMFC and LYMFC as DO biosensor applied in an irrigation canal and b) DO level of water in irrigation canal measured using DO meter, SYMFC, and LYMFC

\subsection{Techno-economic Analysis of Yeast MFC as DO Biosensor}

Our results show a comparable correlation between power output and size of MFC-based biosensors, suggesting that larger MFC sizes can have relatively higher power output when compared to MFCs of smaller size, despite having a reactor, electrode, and membrane type the same one. According to Li et al (2014), the cost is one of the main obstacles to implementing MFC on a larger scale, so that focusing on reducing the capital costs of MFC-based DO biosensor systems becomes an alternative strategy rather than increasing power output.

The next step is to test the economic feasibility of the SYMFC and LYMFC system assemblies by considering each of its parts, including the reactor, anode, cathode, current collector, separating membrane, biocatalyst, and microorganism growth media, which are installed directly into the system. With this, the capital costs of a larger or smaller scale electrode assembly in future generations are estimated, and the cost-effectiveness can be evaluated.

In short, we assume that SYMFC requires $28 \mathrm{~mL}$ of anolyte consisting of media and yeast culture to generate electricity as a DO biosensor. While LYMFC requires a larger anolyte volume of $154 \mathrm{~mL}$ or 5.5 times more than SYMFC. Single-chamber acrylic MFC reactors with aircathode systems used in both the SYMFC and LYMFC systems, have an electrode active surface area of $7 \mathrm{~cm}^{2}$ for SYMFC and $38.48 \mathrm{~cm}^{2}$ for LYMFC with spaces between the electrodes being fixed $(4 \mathrm{~cm})$. 
Table 1

Cost of currently available materials for a small and large MFC system

\begin{tabular}{|c|c|c|c|c|c|c|c|c|}
\hline \multirow{2}{*}{ Component } & \multirow{2}{*}{ Material } & \multirow{2}{*}{ Quantity } & \multirow{2}{*}{ Cost (\$) } & \multicolumn{2}{|c|}{ SYMFC } & \multicolumn{2}{|c|}{ LYMFC } & \multirow[t]{2}{*}{ Manufacturer } \\
\hline & & & & Required & Cost/Cell & Required & Cost/Cell & \\
\hline Cell reactor & Cubic acrylic & 1 set & 53 & 1 set & 53 & 1 set & 80.16 & $\begin{array}{l}\text { Small: Phyhemi } \\
\text { Large: home- } \\
\text { made }\end{array}$ \\
\hline Electrode & Carbon felt & $600 \mathrm{~cm}^{2}$ & 21.18 & $7 \mathrm{~cm}^{2} \times 2$ & 0.4942 & $38.48 \mathrm{~cm}^{2} \times 2$ & 2.7166 & KWS \\
\hline Membrane & Nafion 117 & $516 \mathrm{~cm}^{2}$ & 777.91 & $25 \mathrm{~cm}^{2}$ & 37.69 & $100 \mathrm{~cm}^{2}$ & 150.76 & Sigma Aldrich \\
\hline $\begin{array}{l}\text { Current } \\
\text { collector }\end{array}$ & $\begin{array}{l}\text { Stainless steel } 304- \\
0.05 \mathrm{~mm}\end{array}$ & $3000 \mathrm{~cm}$ & 3.85 & $2.5 \mathrm{~cm}^{2} \times 2$ & 0.0064 & $7.5 \mathrm{~cm}^{2} \times 2$ & 0.0192 & Saky Steel \\
\hline Biocatalyst & $\begin{array}{l}\text { Yeast Saccharomyces } \\
\text { cerevisiae }\end{array}$ & $11 \mathrm{gr}$ & 0.35 & $0.392 \mathrm{gr}$ & 0.0124 & $2.156 \mathrm{gr}$ & 0.0686 & S.I.L. France \\
\hline Media & $\begin{array}{l}\text { - yeast extract } \\
\text { - peptone } \\
\text { - D-glucose }\end{array}$ & $\begin{array}{l}\text { - } 600 \mathrm{gr} \\
\text { - } 500 \mathrm{gr} \\
\text { - } 250 \mathrm{gr}\end{array}$ & $\begin{array}{ll}\text { - } & 128.14 \\
\text { - } & 55.74 \\
\text { - } & 33\end{array}$ & $\begin{array}{l}\text { - } 0.140 \mathrm{gr} \\
-0.070 \mathrm{gr} \\
-0.392 \mathrm{gr}\end{array}$ & $\begin{array}{l}-0.0299 \\
-0.0078 \\
-0.0517\end{array}$ & $\begin{array}{l}\text { - } 0.770 \mathrm{gr} \\
-0.385 \mathrm{gr} \\
\text { - } 2.156 \mathrm{gr}\end{array}$ & $\begin{array}{l}-0.1644 \\
-0.0429 \\
\text { - } 0.2846\end{array}$ & $\begin{array}{l}\text { - Merck } \\
\text { - Himedia } \\
\text { - Merck }\end{array}$ \\
\hline $\begin{array}{l}\text { Cost of } \\
\text { power }\end{array}$ & & & & & 26.23 & & 21.51 & \\
\hline
\end{tabular}

MFC-based DO biosensor assembly costs were calculated based on the current material prices of several producers, as shown in Table 2 . Because price variability depends on location, taxes and shipping costs can be excluded. Our analysis shows that SYMFC will be cheaper at $\$ 91.2924$, but more expensive at $\$ 26.23$ of capital costs per $\mathrm{mW} / \mathrm{m}^{2}$ generated. In contrast, the LYMFC capital cost will be 2.6 times higher, but 1.2 times the lower cost per $\mathrm{mW} / \mathrm{m}^{2}$ (\$234.22 and $\$ 21.51$ per $\left.\mathrm{mW} / \mathrm{m}^{2}\right)$. We find the fact that increasing the power in the biosensor can be directly proportional to the economics of the device; the cost reduction must also be considered. We have shown that the compactness and complexity of MFC size materials cannot guarantee cost savings on an $\mathrm{MFC}$ system.

\section{Conclusion}

In this study, we compared the performance of yeast MFCbased DO biosensors from different sizes, small and large, and also study their techno-economic analysis. The correlation between DO and current density had a nonlinear (exponential) tendency rather than linear, with $\mathrm{R}^{2}$ values of 0.9989 and 0.9979 for SYMFC and LYMFC, respectively. SYMFC and LYMFC as DO biosensors produced maximum power densities of 3.48 and 10.89 $\mathrm{mW} / \mathrm{m}^{2}$. When applied to the irrigation canal, DO measurements showed errors of 3.39 and $4.42 \%$ for SYMFC and LYMFC, respectively, when compared to DO measurements using DO meters. This shows DO measurements using Yeast MFC with various sizes are still acceptable.

The size of the MFC reactor affects the components used as DO biosensors, so the techno-economic analysis needs to be carried out to assess the feasibility of the MFCbased DO biosensors in various sizes. Simple economic analysis showed that for SYMFC, the capital cost of a set of systems equipped with the reactor, electrodes, membrane, biocatalyst, and media would be $\$ 91.29$, or $\$$ 26.23 per $\mathrm{mW} / \mathrm{m}^{2}$ of power generated. While for LYMFC, the capital cost of a set of systems was $\$ 234.22$, or $\$ 21.51$ per $\mathrm{mW} / \mathrm{m}^{2}$ of power generated. This shows that SYMFC is preferred than LYMFC because it only requires fewer capital costs and by considering cost per $\mathrm{mW} / \mathrm{m}^{2}$, which is more or less similar.

\section{Acknowledgments}

This research was supported in full with Kurita Asia Research Grant (19Pid003) provided by Kurita Water and Environment Foundation. The authors would like to thank Indraprasta Setyonadi and Mohammad Rizqi Maulana for collecting data.

\section{References}

Ansa-Asare, O. D., Marr, I. L., \& Cresser, M. S. (2000). Evaluation of modelled and measured patterns of dissolved oxygen in a freshwater lake as an indicator of the presence of biodegradable organic pollution. Water research, 34(4), 1079-1088.

Badihi-Mossberg, M., Buchner, V., \& Rishpon, J. (2007). Electrochemical biosensors for pollutants in the environment. Electroanalysis: An International Journal Devoted to Fundamental and Practical Aspects of Electroanalysis, 19(19-20), 2015-2028.

Bond, D. R., Holmes, D. E., Tender, L. M., \& Lovley, D. R. (2002). Electrode-reducing microorganisms that harvest energy from marine sediments. Science, 295(5554), 483-485.

Cheng, S., \& Logan, B. E. (2011). Increasing power generation for scaling up single-chamber air cathode microbial fuel cells. Bioresource technology, 102(6), 4468-4473.

Christwardana, M., Frattini, D., Accardo, G., Yoon, S. P., \& Kwon, Y. (2018). Optimization of glucose concentration and glucose/yeast ratio in yeast microbial fuel cell using response surface methodology approach. Journal of Power Sources, 402, 402-412.

Christwardana, M., Frattini, D., Accardo, G., Yoon, S. P., \& Kwon, Y. (2018). Effects of methylene blue and methyl red mediators on performance of yeast based microbial fuel cells adopting polyethylenimine coated carbon felt as anode. Journal of Power Sources, 396, 1-11.

Christwardana, M., Frattini, D., Accardo, G., Yoon, S. P., \& Kwon, Y. (2018). Early-stage performance evaluation of flowing microbial fuel cells using chemically treated carbon felt and yeast biocatalyst. Applied Energy, 222, 369-382.

Christwardana, M., Frattini, D., Duarte, K. D., Accardo, G., \& Kwon, Y. (2019). Carbon felt molecular modification and biofilm augmentation via quorum sensing approach in 
yeast-based microbial fuel cells. Applied energy, 238, 239248.

Dennison, M. J., \& Turner, A. P. (1995). Biosensors for environmental monitoring. Biotechnology advances, 13(1), $1-12$.

Duarte, K. D., Frattini, D., \& Kwon, Y. (2019). High performance yeast-based microbial fuel cells by surfactant-mediated gold nanoparticles grown atop a carbon felt anode. Applied Energy, 256, 113912.

Fan, Y., Han, S. K., \& Liu, H. (2012). Improved performance of CEA microbial fuel cells with increased reactor size. Energy \& Environmental Science, 5(8), 8273-8280.

Hadiyanto, H., Christwardana, M., \& da Costa, C. (2019). Electrogenic and biomass production capabilities of a Microalgae-Microbial fuel cell (MMFC) system using tapioca wastewater and Spirulina platensis for COD reduction. Energy Sources, Part A: Recovery, Utilization, and Environmental Effects, 1-12.

Hubenova, Y., \& Mitov, M. (2015). Extracellular electron transfer in yeast-based biofuel cells: A review. Bioelectrochemistry, $106,177-185$.

Karube, I., Nomura, Y., \& Arikawa, Y. (1995). Biosensors for environmental control. TrAC Trends in Analytical Chemistry, 14(7), 295-299.

Lanas, V., Ahn, Y., \& Logan, B. E. (2014). Effects of carbon brush anode size and loading on microbial fuel cell performance in batch and continuous mode. Journal of Power Sources, 247, $228-234$.

Logan, B. E., \& Regan, J. M. (2006). Microbial fuel cellschallenges and applications. Environ. Sci. Technol. 40, 17, $5172-5180$

Lowy, D. A., Tender, L. M., Zeikus, J. G., Park, D. H., \& Lovley, D. R. (2006). Harvesting energy from the marine sedimentwater interface II: kinetic activity of anode materials. Biosensors and Bioelectronics, 21(11), 2058-2063.

Markfort, C. D., \& Hondzo, M. (2009). Dissolved oxygen measurements in aquatic environments: the effects of changing temperature and pressure on three sensor technologies. Journal of Environmental quality, 38(4), 1766-1774.

Oh, S. E., \& Logan, B. E. (2006). Proton exchange membrane and electrode surface areas as factors that affect power generation in microbial fuel cells. Applied microbiology and biotechnology, 70(2), 162-169.

Oh, S. E., Kim, J. R., Joo, J. H., \& Logan, B. E. (2009). Effects of applied voltages and dissolved oxygen on sustained power generation by microbial fuel cells. Water science and technology, 60(5), 1311-1317.

Powell, E. E., Evitts, R. W., Hill, G. A., \& Bolster, J. C. (2011). A microbial fuel cell with a photosynthetic microalgae cathodic half cell coupled to a yeast anodic half cell. Energy Sources, Part A: Recovery, Utilization, and Environmental Effects, 33(5), 440-448.

Rabaey, K., Van de Sompel, K., Maignien, L., Boon, N., Aelterman, P., Clauwaert, P., ... \& Lens, P. (2006). Microbial fuel cells for sulfide removal. Environmental science \& technology, 40(17), 5218-5224.

Rago, L., Cristiani, P., Villa, F., Zecchin, S., Colombo, A., Cavalca, L., \& Schievano, A. (2017). Influences of dissolved oxygen concentration on biocathodic microbial communities in microbial fuel cells. Bioelectrochemistry, 116, 39-51.

Rawson, D. M., Willmer, A. J., \& Turner, A. P. (1989). Whole-cell biosensors for environmental monitoring. Biosensors, 4(5), 299-311.

Reimers, C. E., Tender, L. M., Fertig, S., \& Wang, W. (2001). Harvesting energy from the marine sediment- water interface. Environmental science \& technology, 35(1), 192195.

Rezaei, F., Richard, T. L., Brennan, R. A., \& Logan, B. E. (2007). Substrate-enhanced microbial fuel cells for improved remote power generation from sediment-based systems. Environmental science \& technology, 41(11), 4053-4058.

Rismani-Yazdi, H., Carver, S. M., Christy, A. D., \& Tuovinen, O. H. (2008). Cathodic limitations in microbial fuel cells: an overview. Journal of Power Sources, 180(2), 683-694.

Rossi, R., Cavina, M., \& Setti, L. (2016). Characterization of electron transfer mechanism in mediated microbial fuel cell by entrapped electron mediator in saccharomyces cerevisiae. Chemical Engineering Transactions, 49, 559564 .

Rossi, R., Fedrigucci, A., \& Setti, L. (2015). Characterization of electron mediated microbial fuel cell by Saccharomyces cerevisiae. Chemical Engineering Transactions, 43. 337-342

Schneider, G., Kovács, T., Rákhely, G., \& Czeller, M. (2016). Biosensoric potential of microbial fuel cells. Applied microbiology and biotechnology, 100(16), 7001-7009.

Shantaram, A., Beyenal, H., Veluchamy, R. R. A., \& Lewandowski, Z. (2005). Wireless sensors powered by microbial fuel cells. Environmental science \& technology, 39(13), 5037-5042.

Shen, Y., Wang, M., Chang, I. S., \& Ng, H. Y. (2013). Effect of shear rate on the response of microbial fuel cell toxicity sensor to $\mathrm{Cu}$ (II). Bioresource technology, 136, 707-710.

Tender, L. M., Reimers, C. E., Stecher, H. A., Holmes, D. E., Bond, D. R., Lowy, D. A., ... \& Lovley, D. R. (2002). Harnessing microbially generated power on the seafloor. Nature biotechnology, 20(8), 821-825.

Tront, J. M., Fortner, J. D., Plötze, M., Hughes, J. B., \& Puzrin, A. M. (2008). Microbial fuel cell biosensor for in situ assessment of microbial activity. Biosensors and Bioelectronics, 24(4), 586-590.

Vishwanathan, A. S., Rao, G., \& Sai, S. S. S. (2013). A novel minimally invasive method for monitoring oxygen in microbial fuel cells. Biotechnology letters, 35(4), 553-558.

Wetzel, R. G. (2001). Limnology: lake and river ecosystems. gulf professional publishing.

Yang, H., Zhou, M., Liu, M., Yang, W., \& Gu, T. (2015). Microbial fuel cells for biosensor applications. Biotechnology letters, 37(12), 2357-2364.

Zhang, Y., \& Angelidaki, I. (2011). Submersible microbial fuel cell sensor for monitoring microbial activity and BOD in groundwater: focusing on impact of anodic biofilm on sensor applicability. Biotechnology and bioengineering, 108(10), 2339-2347.

Zhang, Y., Olias, L. G., Kongjan, P., \& Angelidaki, I. (2011). Submersible microbial fuel cell for electricity production from sewage sludge. Water Science and Technology, 64(1), 50-55.

(C) 2020. This article is an open access article distributed under the terms and conditions of the Creative Commons AttributionShareAlike 4.0 (CC BY-SA) International License (http://creativecommons.org/licenses/by-sa/4.0/) 